\title{
The Deposition Temperature Dependence on the Crystallite Size of NiO Thin Films
}

\author{
Said Benramache ${ }^{1, *}$, Foued Chabane ${ }^{2}$, Ali Arif ${ }^{3}$ \\ ${ }^{1}$ Department of Material Sciences, University of Biskra, Biskra 07000, Algeria \\ ${ }^{2}$ Department of Mechanical, University of Biskra, Biskra 07000, Algeria \\ ${ }^{3}$ Department of Electrical, University of Biskra, Biskra 07000, Algeria \\ *s.benramache@univ-biskra.dz
}

\begin{abstract}
In this article, we have investigated a fitting proposal model for calculating the crystallite size of pure $\mathrm{NiO}$ thin films by varying the structural parameters, such as full width at half-maximum $\beta$, lattice parameter $a$ and differences in $a-a_{0}$. The experimental data of $\mathrm{NiO}$ thin films were prepared at several deposition temperatures in the range of $380-460^{\circ} \mathrm{C}$. All estimated values of crystallite sizes are proportional to the experimental data. Thus, the measurement of the crystallite size values by this proposed model is compatible with practical measurements qualitative.
\end{abstract}

Keywords: NiO thin films, deposition temperature, crystallite size, defect structure, fitting.

\section{Povzetek}

V tem delu smo preučili skladnost modela za izračun velikosti kristalnih zrn v tankih plasteh čistega $\mathrm{NiO}$ s spreminjanjem strukturnih parametrov, kot so $\operatorname{FWHM} \beta$, mrežni parameter $a$ in razlika v $a-a_{0}$. Eksperimentalni podatki, pridobljeni iz tankih plasti NiO uporabljeni v modelu so bili pripravljeni pri različnih temperaturah nanosa v območju od 380 do $460^{\circ} \mathrm{C}$. Ocene velikosti kristalnih zrn so skladne z eksperimentalnimi podatki. Na osnovi tega, je meritev velikosti kristalnega zrna po predlaganem modelu skladna s praktičnimi meritvami in predstavlja kvalitativnimi rezultat.

Ključne besede: tanke plasti NiO, temperatura nanosa, velikost kristalnega zrna, strukturne napake, ujemanje 


\section{Introduction}

In previous years, the investigation of new materials for photovoltaic applications was dependent and related to the experimental and modelling parameters of any properties. Nickel oxide was obtained to belong in the group of semiconductor materials and is one of the best materials at present because of its good properties [1].

Nickel oxide (NiO) is a semiconductor material with a nature of p-type, which belonged to the part of TCO family. This attribute of $\mathrm{NiO}$ has several potential applications, for example, it is used in the gas sensors due to its band gap energy in the range of 3.6-4.0 eV and for the organic solar cells applications due to its p-type semiconducting [2]. It can be used in transparent diodes and even in the transparent transistors caused by the best optical transmission and electrical conductivity. Moreover, $\mathrm{NiO}$ can be used for defrosting windows due to its good conductivity, and fabricated $\mathrm{NiO}$ can be used in the UV photodetectors and touch screens due to its good responsivity $[3,4]$.

In the present article, we have studied and investigated a relationship to calculate the crystallite size $(G)$ from the measured structural parameters of the X-ray diffraction in the $\mathrm{NiO}$ thin films. We have used the experimental data of $\mathrm{NiO}$ thin films prepared at several deposition temperatures in the range of $380-460^{\circ} \mathrm{C}$ [5], which present the following parameters, such as the diffraction angle $2 \theta$, the full width at half-maximum (FWHM), the crystallite size $G$, the lattice parameter $a$ and $a-a_{0}$ of (111) diffraction peak for NiO thin films at several deposition temperatures.

\section{Materials and Methods}

The NiO samples were fabricated on the glass substrates using a pneumatic spray technique with $0.1 \mathrm{M}$ of the precursor molarity. The $\mathrm{NiO}$ thin films were deposited at several deposition temperatures in the range of $380-460^{\circ} \mathrm{C}$ [5] (see Table 1).

Table 1 presents that the NiO thin films were nanocrystalline and had a cubic structure with (111) crystal plane at the higher intensity, which has preferential a-axis orientation along with (111) crystal plane.

The Miller indices $(h k l)$ were obtained from the Bragg equation [6]:

$n \lambda=2 d_{h k l} \sin \theta$

where $n, \lambda, d_{h k l}$ and $\theta$ are the integers called the order of diffraction, the wavelength longer of X-ray $\left(\lambda=1.5406 \mathrm{~A}^{\circ}\right)$, the interplanar spacing and the diffraction angle, respectively.

The lattice parameter $a$ of cubic structure for $\mathrm{NiO}$ thin films was determined in Eq. (1) and XRD patterns using the following formula [5]:

$d_{h k l}=\frac{a}{\sqrt{h+k+l}}$

The differences $a-a_{0}$ of (111) crystal plane are given by the following relation [6]:

$a-a_{0}=d_{h k l} \sqrt{h+k+l}$

Table 1. The diffraction angle $2 \theta$, the full width at half-maximum (FWHM), the crystallite size $G$, the lattice parameter a and $a-a_{0}$ of (111) diffraction peak for NiO thin films at several deposition temperatures [5].

\begin{tabular}{cccccc}
$\begin{array}{c}\text { Deposition } \\
\text { temperature Ts }\left({ }^{\circ} \mathbf{C}\right)\end{array}$ & $\mathbf{2 \theta}(\mathbf{d e g})$ & $\boldsymbol{\beta}$ (rad) & $\boldsymbol{G}(\mathbf{n m})$ & $\boldsymbol{a}(\mathbf{n m})$ & $\boldsymbol{a}-\boldsymbol{a}_{\mathbf{0}}(\mathbf{n m})$ \\
\hline 380 & 37.80 & 0.00766 & 19.13 & 0.4122281 & 0.00537184 \\
\hline 400 & 37.67 & 0.00781 & 18.74 & 0.4135872 & 0.00401271 \\
\hline 420 & 37.64 & 0.00868 & 16.88 & 0.4138530 & 0.00374695 \\
\hline 440 & 37.60 & 0.00799 & 18.31 & 0.4143484 & 0.00325152 \\
\hline 460 & 37.66 & 0.00707 & 20.72 & 0.4136507 & 0.00394921 \\
\hline
\end{tabular}


Table 2. The crystallite size $G$ experimental and correlated at several deposition temperatures.

\begin{tabular}{ccc}
$\begin{array}{c}\text { Deposition } \\
\text { temperature } \\
\text { Ts }\left({ }^{\circ} \mathbf{C}\right)\end{array}$ & $\begin{array}{c}\text { Experimental } \\
\text { crystallite } \\
\text { size (nm) }\end{array}$ & $\begin{array}{c}\text { Fitting } \\
\text { crystallite } \\
\text { size (nm) }\end{array}$ \\
\hline 380 & 19.13 & 19.14 \\
\hline 400 & 18.74 & 18.84 \\
\hline 420 & 16.88 & 16.96 \\
\hline 440 & 18.31 & 18.45 \\
\hline 460 & 20.72 & 20.82 \\
\hline
\end{tabular}

where $a_{0}$ is the standard lattice parameter of $\mathrm{NiO}$ (standard $a_{0}=0.4176 \mathrm{~nm}$ ). The crystallite size of (111) crystal plane for the fabricated $\mathrm{NiO}$ thin films was calculated from the Scherer's formula [7]:

$G=\frac{0.9 \lambda}{\beta \cos \theta}$

where $G$ is the experiment crystallite size, $\beta$ is the FWHM and $\theta$ is the diffraction angle peak (see Table 1).

\section{Results and Discussion}

In this article, we have estimated the crystallite size $(G)$ by fitting relationships between the structural parameters $\left(\beta, a\right.$ and $\left.a-a_{0}\right)$, which is detected in the following empirical relationship:

$G=C_{1} \frac{a}{\beta}-C_{2} \frac{a-a_{0}}{\beta}$

where $C_{1}$ and $C_{2}$ are constants as $C_{1}=0.365$ and $C_{2}=0.02$. The results of this fitting are given in Table 2.

Figure 1 shows the variation of the experimental and fitting of the crystallite size at several deposition temperatures in the range of $380-460^{\circ} \mathrm{C}$. The measured values of the crystallite sizes were obtained using Eq. (5), which were given in Table 2. This correlation indicated that the crystallite sizes of the $\mathrm{NiO}$ thin films can be predominantly influenced by the

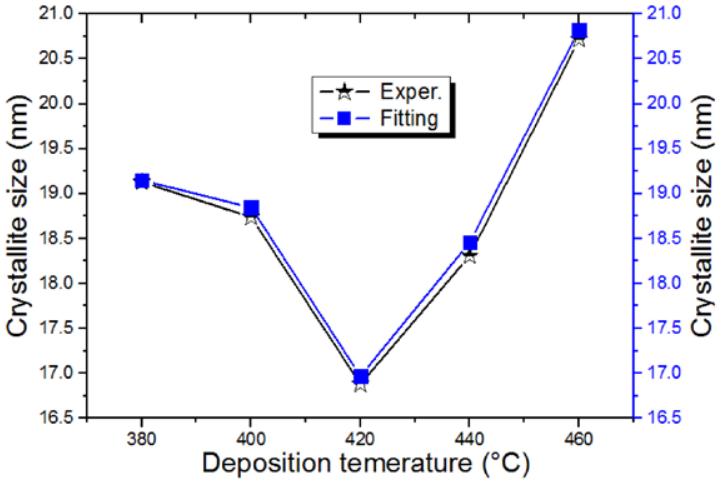

Figure 1. The variation of the crystallite size G experimental and fitting at several deposition temperatures.

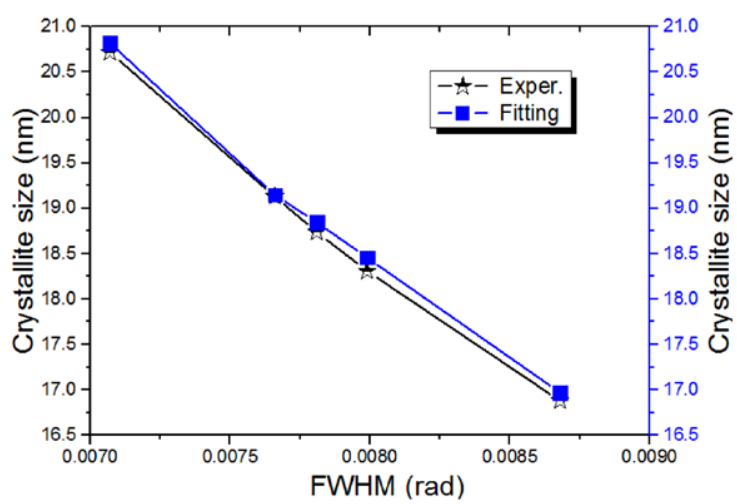

Figure 2. The variation of the crystallite size G experimental and fitting at several FWHM values.

FWHM $\beta$, the lattice parameter $a$ and the differences in $a-a_{0}$ of the $\mathrm{NiO}$ thin films. As seen, all estimated values of crystallite sizes are proportional to the experimental data. Thus, the measurement of the crystallite size values by this proposed model is compatible with practical measurements qualitative. This attribution can be observed with the variation of FWHM $\beta$ (see Figure 2). This observation was investigated to demonstrate that the calculation of the crystallite size can be influenced by the measurements of the structural parameters $\left(\beta, a\right.$ and $\left.a-a_{0}\right)$.

\section{Conclusions}

In this article, the direct correlation of the crystallite size from the experimental values was investigated by a fitting model wherein the calculated crystallite size of the pure $\mathrm{NiO}$ thin films was detected in the structural parameters, such 
as the FWHM $\beta$, the lattice parameter $a$ and the differences in $a-a_{0}$. The experiment data of $\mathrm{NiO}$ thin films were prepared at several deposition temperatures in the range of $380-460^{\circ} \mathrm{C}$. All estimated values of crystallite sizes are proportional to the experimental data. Thus, the measurement of the crystallite size values by this proposed model is compatible with practical measurements qualitative.

\section{References}

[1] Diha, A., Benramache, S., Benhaoua, B. (2018): Transparent nanostructured Co doped NiO thin films deposited by sol-gel technique. Optik, 172, pp. 832-839.

[2] Lamastra, F.R., Nanni, F., Menchini, F., Nunziante, P., Grilli, M.L. (2016): Transparent nanostructured electrodes: Electrospun NiO nanofibers/NiO films. Thin Solid Films, 601, pp. 54-58.

[3] Hotovy, I., Spiess, L., Predanocy, M., Rehacek, V., Racko, J. (2014): Sputtered nanocrystalline NiO thin films for very low ethanol detection. Vacuum, 107, pp. 129-131.

[4] Ali, N., Hussain, A., Ahmed, R., Wang, M.K., Zhao, C., Haq, B.Ul., Fu, Y.Q. (2016): Advances in nanostructured thin film materials for solar cell applications. Renewable and Sustainable Energy Reviews, 59, pp. 726-737.

[5] Charef, A., Benramache, S., Aoun, Y., Benhaoua, B., Lakel, S., Marrakchi, M. (2019): Effect of Substrate Temperature on the Growth and Properties of Nanocrystalline NiO Thin Films. Journal of Nanoelectronics and Optoelectronics, 14, pp. 1667-1671.

[6] Aoun, Y., Marrakchi, M., Benramache, S., Benhaoua, B., Lakel, S., Charef, A. (2018): Preparation and Characterizations of Monocrystalline Na Doped NiO Thin Films. Materials Research, 21(2), pp. 1-5.

[7] Sharma, R., Acharya, A.D., Shrivastava, S.B., Patidar, M.M., Gangrade, M., Shripathi, T., Ganesan, V. (2016): Studies on the structure optical and electrical properties of Zn-doped NiO thin films grown by spray pyrolysis. Optik, 127(11), pp. 4661-4668. 